DOI https://doi.org/10.36059/978-966-397-209-1/17-33

\title{
THE PSYCHOLOGICAL CONTEXT OF SOME CONCEPTS OF POSTMODERN PHILOSOPHY
}

\section{Hrabovska S. L.}

\section{INTRODUCTION}

If you try to present the concept of modern psychology, its scientific and practical field, in the metaphoric form, the first thing that comes to mind is a huge, colorful, lively shopping and entertainment center. Within, there's everything you want: shops with goods for every taste and purse, children's playgrounds, cinemas, cafes, restaurants, cozy walkways, hairdressers, dry cleaning and even swimming pools. It's even hard to list. You can satisfy here any of your needs, desires, whims. But is all this diversity, though gathered under the common roof, making up a unified system? What is the core that unites individual particles and constituents? The simplest answer is: this is the person with his or her colorful and complex world, and all the resources are created and accumulated to meet his or her needs.

Similarly, the modern psychology seeks to explore the innermost corners of the human soul, in the aim to predict its motives (and often to stimulate their emergence) and to create techniques and means for their satisfaction. The colossal industry of psychotherapy, with its endeavor to respond to a wide variety of client requests, raises numerous questions before academic science, provoking the study of individual features, nuances of mental phenomena and processes. The hopes of creating a common and totally admitted concept of the psychic, which would describe and consistently explain the psychic as an individual and, at the same time, a social phenomenon, in the near future seems to be unfulfilled. It is clear that generalization of ideas about the psychic's nature and general mechanisms of it requires raising to a high level of abstraction, which, in turn, will require a philosophical generalization. Although psychology, for the last 150 years of its existence, has been trying to separate itself from philosophy, nowadays we can see some integration tendencies. They are especially clearly evident in the relations between the postmodern philosophy and psychology: despite the declared philosophy's "antipsychologism" and psychology's "independency of philosophy", we can observe philosophy immersing deeper and deeper of into the terrain of psychological problems, and psychology borrowing more and more of philosophical methodology.

Therefore, the present article is aimed to identify the psychological context of certain ideas, approaches and concepts of postmodern philosophy, which 
seem to be the most important in the process of conceptualization of psychological research. The free spirit of postmodernity rejects value judgments, forbids to encroach on completeness and exhaustiveness in any analysis, it allows the presentation to be made in the form of a colorful patchwork (or a library full of assorted books), not in a strict perfect system. So, let's try to find the psychological content of some of the postmodern philosophy concepts. First of all, attention will be drawn to such concepts as rhizome, transgression, nomadology, synergy, discourse, identity. Of course, other concepts of postmodern philosophy can also be interpreted psychologically and have already functioned successfully in psychology for a long time, but the volume of the article imposes certain limitations.

The concept of rhizome (fr. rhizome - roots) is borrowed from botany, where it denotes the type of branched roots with no main stem. A rhizome is a fundamentally non-hierarchical structure, each part of which interacts with another without a predetermined order, and the relationships between those parts are unique, ambiguous, and individual ${ }^{1}$. The stability and viability of the rhizome is ensured by the absence of the center and the connection of each part with all the other ones. That is why, grass is more resistant than trees, when the storm comes. This concept was introduced into the philosophy by J. Deleuze and P.-F. Guattari, who were intending to contrast a sustainable and viable culture of postmodern with an outdated traditional European culture, based on formal logic, determinism, and traditions that have remained unchanged for centuries ${ }^{2}$.

We can agree with the statement of R. Garifullin: the psychic in its nature is fundamentally rhizomic, since all its elements (or at least most of them) can perform their functions simultaneously ${ }^{3}$. This metaphor also fits into the understanding of a person's social adaptation mechanisms: the more diverse are social roles, stronger and more branched are social ties of a person, better is his or her communicative competence - the more easily this person adapts to changes, is more satisfied with life, and has a higher level of psychological welfare. At the same time, the rhizome metaphor makes a good illustration for the person's motivational sphere: a wide variety of motivation vectors makes a much more comfortable state than if the field of motivation is narrowed to a single but very powerful motive. When the realization of such an

\footnotetext{
${ }^{1}$ Мерфі Т. Ризома // Енциклопедія постмодернізму / за ред. Ч. Вінквіста, В. Тейлора. Київ, 2003. С. 361-362.

${ }^{2}$ Гваттари Ф., Делез Ж. Тисяча Плато. Капитализм и шизофрения. / Пер. с франц. и послесл. Я.И. Свирского, научн. ред. В.Ю Кузнецов. Екатеринбург : У-Фактория ; Москва : Астрель. 2010. 895 с.

${ }^{3}$ Гарифуллин P.P. Постмодернизм в психологии : монография. URL: http//psyfactor.org/ lib/postmodern-00.htm. 2010
} 
overpowering motive seems impossible or threatened, a serious risk emerges to fall into a state of frustration or to lose the meaning not only of a specific action, but also of life in general. One pivotal motive may evoke such powerful emotional tense that it alone is capable to upset or even block all the activity. The presence of an extensive system of more or less equivalent motives reduces stress, allows rational planning and implementation of actions for their satisfaction, making the activity more effective.

Transgression is one of the key concepts of postmodernism that captures the state of a person overcoming an insurmountable border (according to $\mathrm{M}$. Blanche), a gesture aimed at the border, an experience of becoming (according to M. Foucault), a concept that means crossing a border that cannot be crossed (rather, going beyond) and explaining the fear of a person approaching the unknown (fear of death, experiencing one's limitations, the mortality of oneself, etc.). It is a condition of a person facing not an everyday life task, for which he or she is prepared by the sum of rules learned during training, but in fact a real problem: old familiar knowledges and skills do not work anymore, algorithms that previously ensured success do not give any result, and you need to create new tools, find your own solution. The fact that a problem exists is evidenced by negative experiences that are caused by unmet needs. Here arises a paradoxical state of knowledge about ignorance. According to Blanchet, the transgressive transition is the way out, the solution of the problem. Consistent with this idea seems the "Rubicon" model of motivation by H. Heckhausen and P.M. Holwitzer, which is quite popular in psychology. Since Gaius Julius Caesar risked breaking the ban and made his army cross the Rubicon River that served as the border (and, that is worth noting, won the battle), the phrase "to pass the Rubicon" became synonymous to "cast thrown", and is symbolizing the conditional or imaginary border, which intersect causes inevitable, but unpredictable consequences. The Rubicon is a symbol of an irreversible and very risky solution. H. Heckhausen argues that human behavior can be motivated internally (intrinsically) or externally (extrinsically). He considers motives as cognitive constructs that can be conditionally inscribed in the explanation scheme of reality between the initial circumstances (the observed situation) and the behavioral reactions. These are relatively stable value dispositions, personally meaningful goals. Therefore, unlike A. Maslow and his followers, H. Heckhausen does not attribute physiological needs to human motives. According to this model, motives may be the following: social needs, urges, inclinations, higher intellectual aspirations.

In general, the motivational state of consciousness shapes a person's behavior, concluding it in a sequence of stages:

- choice of the aim;

- activation of volitional processes under conditions of motive struggle; 
- development of a goal achievement plan;

- realization of the plan;

- evaluation of the effectiveness of actions;

- if necessary, correction of the strategy and implementation of the corrected action.

Simultaneously combining and clearly delineating will and motivation in his theory, H. Heckhausen in the "Rubicon" metaphor emphasizes the importance of the moment of overcoming the gap between intentions, motivation and actions, confusion and expression of will. Motivational processes, according to this theory, are initiated by the desire to satisfy certain needs and fear of the actions' consequences. These experiences prompt the person to check how attainable is what he or she was striving for (or whether the cause of fear could actually be prevented). Therefore, determining whether a goal can be realized, the subject should make a maximum possible realistic prediction of the consequences of his actions ${ }^{4}$. The Rubicon model aims to clearly distinguish between the "decision to act" and the regulation of the "decision made" action. The decision-making process as a cognitive component forms person's intentions, and the volitional component regulates the actions. All this allows the person to force him- or herself to consistently implement the outlined plan, not distracting by extraneous or insignificant factors.

In many psychotherapeutic techniques, the above-described transgressive state is used to enhance the will to live (existential psychotherapy), to become aware of one's resources and to activate the choice of the most important things, to stimulate the ability to solve problems (gestalt therapy), to enhance self-efficacy and to formulate effective self-management patterns (cognitivebehavioral psychotherapy), etc. In general, psychotherapy often appeals to "step out of the comfort zone", that should encourage the client for changes, innovations and search for something new.

But at the same time, it is worth noting that not all modern psychologists consider this never ending search for new and focusing on boundless development as a positive feature of modern civilization. Thus, L. Zoja raises the question of whether we should consciously limit our desires and where humanity will be led by this constantly encouraging growth of each person's needs in nowadays consumer society. He emphasizes, "Not civilization had invented the self-restraint and imposed it on the instinct. Vice versa. Natural life is self-regulating. Trees do not grow to heaven. And humans have also reproduced this natural need for

${ }^{4}$ Heckhausen H. (2010) Motivation and Action (PDF) (Paperback 2nd ed Cambridge University Press. Pp. 272-295. 
borders for a long time" . The problem of boundaries resonates with the idea of the sense of proportion that has been recognized by philosophers since ancient times. After all, one does not need to be a philosopher to understand that everything within a certain "measure" (or "norm") can be good, positive, useful, but ceases to be so as soon as it crosses the limits of this measure, goes beyond the "norm". For example, adults like lively children; but when their liveliness crosses a certain boundary, those children are taken to doctors, diagnosed with "hyperactivity", and adults try to return their behavior within the limits of "normal liveliness", using therapy and pills.

So, we see that in psychology, as well, the concept of transgression has many uses and cannot be interpreted unambiguously.

Nomadology is a concept proposed by P.F. Guattari and J. Deleuze and supported by other postmodern philosophers who deny the determinism of modernist philosophy with its dichotomous division (internal - external, past - future, good - evil, female - male), with an unwavering belief in the laws of nature, and postulating that sense is immanent to objective things and is revealed to the subject in the process of cognition. In its turn, the postmodern philosophy proclaims a fundamentally unpredictable, non-linear, chaotic, situational development, some kind of "astructural" organization of integrity that allows infinite variations for creative self-organization. J. Deleuze and P.-F. Guattari compared chess, with clearly defined rules, and go, game of nomads, where the rules are determined by the situation, the configuration of falling stones in the sand, and change every time. They contrast the model of European culture, rigidly regulated and therefore incapable of quickly responding to the changing situation, and the model of a new postmodern culture: creative, situational, freed from clearly defined trajectory. The "settled", inert, old European culture has "taken a deep root" and therefore broken away from normal daily life and lost the ability to respond to the rapid changes that are occurring in society. According to postmodernists, the nomadic culture responds instantly to the smallest changes in social life, because its rhizomic, astructural organization has everything connected to everything and operates on the principles of feedback, making it more stable, more enduring and more fruitful ${ }^{6}$.

The idea of nomadism makes a quite interesting illustration of the changes in the cultural paradigm, from an authoritarian society to the democratic one, with increasing rate of personal freedom, and also of the changes in the

\footnotetext{
${ }^{5}$ Дзоя Л. Історія гордині : психологія і межі розвитку / перекл. з італ. С. Сарвіра ; за фах. ред. Д. Залеського. Львів : Видавництво “Астролябія”. 2019. С. 31

6 Делез Ж., Гваттари Ф. Трактат о номадологии // Новый круг, 2005, № 2 (92). C. $183-187$
} 
collective consciousness that incarnate in the idea of "free people of a free society". Any authoritarian society creates a culture of "habitation", with a fixed place of residence, constant social roles, lack of choice, predestinated fate, almost total predictability of all events; all this, on the one hand, reduces the feeling of uncertainty and stress, but on the other, makes the person apathetic and submissive. Many people are willing to obey someone else's will because this allows them to "make a deal" with their conscience and not suffer of guilt and self-blame in any situations, even when these people have to do something contrary to their moral principles. It seems that the personality cults of the most violent rulers grow out exactly from the described phenomenon. This was eloquently proved by the cruel experiments of S. Milgram, when the test subjects, at the instruction of the experimenter, struck the "victim" with increasing and even life-threatening powers of electric shock.

In a democratic society, with its transparent borders, with an opportunity to choose everything in your life: from toothpaste to religion, a person becomes a "human of the world" and is constantly confronted with the problem of choice, which often causes internal conflicts. Freedom of choice has the downside: the tension of responsibility. If one is forced to make choices, they are usually very meticulous and critical about what they have chosen, and compare their "tit in the hands" with idealized images of untapped opportunities - with the unreachable "cranes in the sky".

The "nomad" metaphor is also interesting in that perspective that the nomad in his wanderings is guided by his own purpose; getting into another culture, he usually does not assimilate it: he carries his world with him. This metaphor explains quite deeply why people have different views of one situation, why conflicts emerge. It ultimately opens up the psychological roots of the postmodern philosophy itself: here we can agree with J. Deleuze, who defines the "meaning" as a problem ${ }^{7}$ that has to be solved, but not simply found, understood, or "borrowed" from someone.

Synergetics is an approach proposed by the school of I. Prigozhin, when individual systems and the world in general are regarded as self-organizing, fundamentally non-linear, unbalanced, evolving on the principles of bifurcational changes, time reversal, and so on. Global evolutionary processes are regarded as "order via chaos" (I. Prigozhin), and their fundamental characteristics are instability and imbalance ${ }^{8}$. This approach seems fruitful for understanding of both individual problems and group dynamics. Despite the

\footnotetext{
${ }^{7}$ Делез Ж. Логика смысла. Москва: Академический проект, 2011. 472 с.

${ }^{8}$ Грицанов А.А., Мезяная К.Н. Пригожин // Новейший философский словарь : 3-е изд., исправл. Минск. : Книжный Дом, 2003. С. 798-799.
} 
fact that psychologists are in a constant search for certain patterns of individual and group behavior, only few researchers dare to declare revealed dependencies as "laws", because they are, in fact, probabilistic in nature. Human life in general and behavior in specific situations are fundamentally non-linear, and reactions to the influence of other people or circumstances rarely may be unambiguous and completely predictable. Determinism in psychology can be applied only in the form of the most general requirement, which is that, in principle, psychic phenomena and peculiarities have some reasons for which they are based. Important concept of the synergistic worldview, the "bifurcation point", can be applied in developmental psychology to understand the essence of age crises. According to I. Prigozhin and I. Stangers, a small perturbation near the bifurcation point can lead to dramatic changes in the direction of further development; small causes have great consequences ${ }^{9}$. Age-related crises in human life are very similar to the "cascades of bifurcations" that generate the branching opportunities for the development of personal life paths. For example, a chance meeting of two young people ("a small perturbation") can turn into a great love of their lives and completely change their inner world, creating a brand new life scenario (dramatic changes in the direction of development).

Among supporters of the synergistic approach we can mention P. Cruz, M. Stadler, G. Haken, A.V. Holden and some others, who share an opinion that personality and society are fundamentally non-equilibrium systems, and their self-organization is carried out nonlinearly at the intersection of random conditions, differences and coincidences. The classics of the synergistic paradigm rightly warn against the direct transfer of the ideas of synergy from the natural sciences to the social ones: any absolutization (of neither determinism nor contingency) leads to one-sided (and therefore limited and narrowed) view of the object of study. E. Toffler rightly emphasizes that the synergistic paradigm is interesting because it focuses on that aspects of reality that are most characteristic at the current stage of social changes: varying degrees of orderliness, variegation, imbalance, nonlinear relations, when a small signal can cause random power of the output response, the importance of temporality as a sensitivity to time flow ${ }^{10}$. Thus, the use of a synergistic approach in psychology directs the researchers of psychological phenomena and the consulting psychologists or psychotherapists to keep a deep attention at seemingly insignificant events in the person's life, which can serve as a

\footnotetext{
${ }^{9}$ Пригожин И., Стенгерс И. Порядок из хаоса. Новый диалог человека с природой. Москва : Прогресс, 1986. 432 с.

${ }^{10}$ Тофлер Е. Третя хвиля. Київ : Вид. дім “Всесвіт”, 2000. 480 с.; Тофлер Э, Тофлер Х. Революционное багатство. Москва : АСТ, 2005. 416 с.
} 
starting point for the deployment of essential, decisive consequences. Such point of view opens up new possibilities both in understanding psychic phenomena and in developing psycho-corrective techniques to assist clients in overcoming of their problems.

For improving the methodological base of psychological research, seem to be fruitful the following approaches, identified by K.L. Pike as "emic" and "etic". Emic, according to his idea, is an approach that emphasizes on something specific, unique, peculiar to a particular culture. It allows us to understand the culture "from inside", to dive into the depth of its symbols and meanings. In psychology, this approach has been implemented most completely by humanistic psychologists. Emic is aimed at studying individuals in their daily lives, their personality traits, motivations, aspirations, etc. Studying behavior "from the inside", from the perspective of its subject, can clarify a lot in terms of theoretical understanding of the mechanisms of this behavior, it can allow us to predict further actions of the studied person, help to choose the best way to solve life problems. Although the method of included observation has been known in psychology for a long time, but now, "out of the hand" of postmodern methodologists, it is gaining popularity as an ethnographic study, providing the researcher to be integrated directly for a quite long time (half a year, a year, and sometimes even longer) into the social life of the subjects in order to reveal the peculiarities of the studied phenomena under natural conditions ${ }^{11}$.

"Etic" characterizes the common and universal features of culture, behavior, attitudes, ideology, etc. Etic allows for a perspective vision, it postulates that different events are similar or different in general terms and patterns, making the basis for the technique of describing different phenomena. This approach can be used for the first assessment, the construction of a research plan, based on the fact that each phenomenon has its cause, quantitative and qualitative characteristics, connections with other phenomena, evolves from simple to more complex forms, has an essence manifesting in certain facts, etc. This simplifies the research process, reduces the amount of all-kind resources needed for finding unique approaches.

Discourse (from Latin discere - to wander) is a form of objectification of the content of consciousness, regulated by the type of rationality that is dominant in a particular socio-cultural tradition ${ }^{12}$. According to M. Foucault, discourse depersonifies the thought, it transforms the subject into a function of

11 Браймен А., Белл Э. Методы социальных исследований. Группы, организации и бизнес / Пер. с англ. Харьков : Изд-во Гуманитарный Центр, 2012. С. 443-477.

12 Можейко М.А., о. Сергий Лепин Дискурс // Новейший философский словарь: 3-е изд., исправл. Минск : Книжный Дом, 2003. С. 327. 
discourse as a meaningful and self-sufficient form of knowledge in a particular culture. The ontology of the subject can be disclosed in different dimensions: in attitude to oneself, in relation to other people and social institutions, and above all, to the authorities, which results in the ontology of the subject in relation to the truth ${ }^{13}$. After all, "wandering" is a form of "nomadic" life. Discourse as a general opinion does not need an author.

The famous metaphor by M. Foucault, that the birth of the Reader is paid for by the death of the Author, in fact illustrates this impersonation of knowledge. Because the Latin word discursus can also be translated as cycle, sprawling, branching, it conveys quite deeply what is happening with knowledge while it is transforming into a cultural heritage: researchers, by publicizing their ideas and discoveries, alienate them, and the ideas start living their separate lives. The one who gains this knowledge assimilates these ideas, appropriates them by understanding, makes them part of his or her identity. The modern civilized person is hardly capable of clearly distinguishing his or her own ideas and thoughts from the ideas and opinions of others, adopted through learning. Here emerge new contradictions of both general and individual order: impersonal knowledge is not discharged from liability for its quality (truth). In the art, a nowadays creator can take pleasure in the idea that anything he wants to call art actually becomes one. However, in science the criteria of scientificity remain valid for all. What is not systematic, grounded, proven, what cannot be reproduced and applied - still should not be recognized as scientific data. That is why M. Foucault, J. Derida and other postmodern philosophers associate discourse not much with the scientific way of thinking, but rather with creativity that is fundamentally unpredictable, accidental, original.

According to M. Foucault, discourse as a method is based on the following basic principles:

- rollover - that is explained as "decimation" and "negative dissection game";

- discontinuity - discourses are considered as intermittent practices that intersect, sometimes coexist, sometimes ignore or exclude one another;

- specificity - discourse is a kind of violence, exerted by the cognition process over things and generally the world, because the subject not only decipher the laws and rules of the world and individual things, but, in the process of cognition, imposes certain practices on the studied object;

- the rule of the external - in the analysis it is important not to go from discourse to its hidden inner core, but, taking the discourse itself as the basis,

${ }^{13}$ Фуко М. Порядок дискурса // Фуко М. Воля к истине: по ту сторону знания, власти и сексуальности. Работы разных лет / Пер. с фран. Москва : Касталь, 1996. С. 47-95 
to look for external conditions of its realization, to find out what allows a random series of certain events and fixes their boundaries ${ }^{14}$.

In psychology, the outlined problems are considered both in personal and processual context. The content of consciousness always has a personal connotation. In the process of assimilating the knowledge, a person filters it through a sieve of his or her value-motivational sphere, choosing what is close to him or her personally and rejecting the unacceptable. Cognition and creativity are complex psychic processes that are carried out by certain mechanisms and are effective not only due to chance coincidence, but make result of a peculiar combination of regular and random, linear and nonlinear. In order to be successful, a person needs both creative and algorithmic thinking. Algorithmic thinking is gained during many years of training by developing skills and abilities to solve standard problems, according to certain standardized laws. The ability to use algorithms shortens the process of problem solving, and also reduces the tension in the decision-making process, as it allows shifting a significant amount of responsibility for the results to the author of the algorithm. But if we accept the idea of the "death of the Author", and providing that no author names were saved for most of the rules, then the responsibility is dissolved in a generalized, conventional algorithm. Algorithmic thinking works on the principle that one should do only what is allowed.

Creative thinking usually has a name: it's the thinking of the Author. The paradox of creativity lies in the combination of freedom and responsibility. The common thing does not have a name; and idea created by someone is named after the Author. The principle of creative thinking can be formulated as follows: it is necessary to determine what is forbidden and to make maximum use of what is not forbidden, going beyond what is allowed. The range of what is "allowed" turns out to be far less than that of the "not forbidden". It is difficult to find something new within the limits of what is directly allowed, but in the area of the non-prohibited we can find resources to get enough combinations. Therefore, creativity is an almost unlimited freedom of choice, and at the same time it is linked to the responsibility for that choice, since the creator is unable to remain anonymous or hide behind the backs of his predecessors. This is probably why the mass culture tends to be impersonal and does not need an Author. The overwhelming majority of people are likely to follow the rules within the limits, and only a small percentage of the brave encroach on creativity, actually creating a culture and ultimately making the rules and algorithms for those submissive masses.

After L. Zoja's position, the desire to create and to be recognized as the Author of one's own creation must be regarded as an expression of vanity and

\footnotetext{
${ }^{14}$ Фуко М. Порядок дискурса // Фуко М. Воля к истине : по ту сторону знания, власти и сексуальности. Работы разных лет / Пер. с фран. Москва : Касталь, 1996. С. 78-79.
} 
should be punished ${ }^{15}$. This contradiction between the assessment of the ability to create as an indicator of personal maturity and the ability to self-realization, on the one hand, and as an encroachment on the role of the Creator of the World, on the other, is important for psychology in both theoretical and practical terms.

Identity (from Latin. identificare - to identify) in philosophical discourse is regarded as the correlation of something ("being") with itself in the connectedness and continuity of one's variability and conceivable in that capacity (the "observer" who tells "the others" of himself to confirm one's self-identity $)^{16}$.

F. Brentano briefly defined identity as a coherence thought in perfection. It is difficult to come up with something more precise and witty. Psychology, referring to this idea, usually considers identity as a result of the process of the person's identification in different dimensions, as awareness and experience of belonging to a wide variety of groups (social, sexual, gender, age, professional, ethnic, religious, cultural, etc.). For the first time in psychology, the concept of identification as a process of identity formation was proposed in psychoanalysis to indicate one of the most important human mechanisms of psychological protection against the pressure of instincts: the baby's unconscious imitation of the mother's actions, based on the first emotional attachment and the fusion of the child and its mother, and the becoming of a Super-Ego through internalization of moral principles, values, norms, parental or reputable adults' prohibitions.

Later, identification in psychology took on a wider meaning, and in different fields this concept is treated differently: for example, in social psychology identification is regarded as the person's affiliation with a certain social group; in the psychology of cognitive processes - as identification of objects, recognition of objects and phenomena; in age psychology - the unconscious identification of oneself to a "meaningful other" as an emotionally attractive standard, and so on. The subjective, filled with meanings, person's world is mastered by oneself through a wide range of roles, which make a dynamic expression of person's social status at every stage of his or her development.

Depending on the methodological paradigm, personal identity is treated differently. As already noted, psychoanalysts consider identity as one of the most important mechanisms of formation of child's gender roles, which occurs through unconscious identification with a significant adult of the same

\footnotetext{
15 Дзоя Л. Історія гордині : психологія і межі розвитку / перекл. з італ. С. Сарвіра ; за фах. ред. Д. Залеського. Львів : Видавництво “Астролябія”. 2019. 384 с.

${ }^{16}$ Абушенко В.Л. Идентичность // Новейший философский словарь : 3-е изд., исправл. Минск: Книжный Дом, 2003. С. 400.
} 
gender. According to the epigenetic approach proposed by E. Erickson, the ego-identity arises in the process of personality development during the crisis of adolescence, if this crisis unfolds in a positive scenario, as a synthesis and integration of identities. Identity, according to E. Erickson, is a single, pivotal internal mechanism that makes a person whole; through its mediation, a person acquires his or her own "I", which becomes systemic and integrated ${ }^{17}$.

In cognitive psychology, identification is associated with differentiation of people's behavior depending on the peculiarities of development of their intelligence, and identity is considered as a result of step-by-step cognition, deepening, expansion and assimilation of information about norms of social behavior. Humanistic and existential paradigms, studying the problem of identity, emphasize on the conscious choice of the person's vital values and principles, their deep reflection, correlation with the self-image of the individual, the congruence of person's life goals and meanings.

The "subject-activity" and "subject-deed" approaches treat identity as an indicator of prolongation, continuity and integrity of consciousness, the unity of a person's perceptions of his or her life perspective with everyday actions and moral deeds. The subject-subject interaction context is interpreted as the deployment of dialogical communication in the "I-Others" system. According to V. Tatenko, "the "by-act" determination of a person as a subject of individual mental, psychic and spiritual life gives the necessary and sufficient substantive concretization, since it fills the individual life with social meaning and sense ${ }^{18,}$.

Postmodernists proclaim the idea of ontological and anthropological crisis of identity. By J.F. Lyotar, the common moral norms and frameworks (metanarratives) have disappeared, and the individual makes his or her own decisions about choosing identities and social roles ${ }^{19}$. So, the person becomes marginalized, loses the established, traditional social roles. The human of the transgressive transition age is a nomad on the path he or she has chosen by his own. According to M. Foucault, the test of the limits that we ourselves must overcome is the work of ourselves over ourselves as free beings ${ }^{20}$. Subjectivity, according to F. Guattari, is the totality of deterritorization processes, multiply (rhizomatically) entangled movements on the existential territories, which is defined as energy discursivation, opening to a person the possibility of numerous close and distant living plans.

17 Эриксон Э. Детство и общество. Санкт-Петербург : ЛЕНАТО ; АСТ; Фонд “Университ. кн”, 1996. С. 392.

18 Татенко В. Суб'єктно-вчинкова парадигма в сучасній психології // Соціальна психологія, 2006, № 1. С. 12.

${ }^{19}$ Лиотар Ж.-Ф. Anima minima // Кабинет “3” / под ред В. Мазина. 2004. С. 62-97.

${ }^{20}$ Фуко М. Что такое Просвещение? // Фуко М. Интеллектуалы и власть. Москва : Праксис, 2002. Ч. I. С. 354. 
So it is not surprising that for the modern nomad who identifies himself as a "human of the world", language becomes an urgent problem. Actually, the language structures not only the conscious but also the unconscious; it introduces certain elements of orderliness and regularity, since it is an external system in relation to the mental and has clearly regulated rules.

Language is an extremely interesting phenomenon: a humanity that created a language seems similar to a constitutional monarch, or the absolute idea by G. Hegel. Language is created by humans to capture, store and transmit certain content across time and space, and therefore the rules for the formation and conversion of words and sentences were created and fixed on a "contractual basis", but after registration they gain the force of an inviolable law, which users should adhere to. Speech, as a mastery and use of language, is a mental cognitive process and therefore appears to be derived from language as something primary to a particular individual. Attachment to culture, assimilation of cultural goods, socialization and in general the development of personality, the essential knowledge of the world seems to be impossible without language and speech. And since, having mastered the language, a person uses it as an instrument in almost all spheres of life and activity, so become clear the theses of postmodern philosophers and psychologists that the reality is linguistic, that human personality and life in general are self-narratives, etc.

An interesting illustration may be the use of descriptions of the characters' language in the story "Ebony Tower" by J. Fowles, as the most important characteristic of them to create a bright image. To show the differences between the main characters in relation to the art and to the world in general, the writer provides one of them, the elderly artist Henry Bresley, who can perfectly convey on canvas the feelings and the inner world of his model, with a rough, sloppy and grammatically incorrect speech; and the abstractionist David Waddy, who does not describe nature, but actually constructs his paintings, speaks grammatically correct, colorful, even logically sophisticated. In another story by J. Fowles, entitled "Poor Coco", a writer (who embodies the older generation of intellectuals) tries to unravel the eternal mystery of unacceptance of the parents' world by their children through the dissonance of their languages, the misunderstanding of the meanings given by the each side to the same words or expressions ${ }^{21}$.

After all, in multilingual states often arise major social problems, and even conflicts, regarding preferences for certain languages, the national language

${ }^{21}$ Фаулз Дж. Пять повестей: Башня из черного дерева. Элидюк. Бедный Коко. Энигма. Туча / Пер. с англ. Москва : АСТ: АСТ МОСКВА, 2008. 444 с. 
status, appointment of a language of education, official documentation keeping, official communication, etc. And Ukraine is not far behind. This was clearly shown by the results of a representative survey of the adult population of Ukraine (aged over 18 years), entitled "Language Question: Pros and Cons", which was conducted by the sociological group "Rating" in July 2012 in the process of discussing the draft law on regional languages. Only $15 \%$ of 2000 people surveyed in all regions of Ukraine indicated that they were not concerned about the problem of adopting a law on regional languages. The overwhelming majority of respondents indicated that they were personally concerned about the issue, since the status of a particular language in the state is associated with a person's ethnic and socio-status identification, with satisfaction of his or her need for recognition ${ }^{22}$.

An important point in understanding the place of language in the development of the culture is the postmodernists' analysis of the dialectic of text: its generation and appropriation in the process of understanding. R. Barthes develops the idea of a "text erotic", when creativity is seen as a rush and discovery of a fundamentally new, non-linear in principle, temporary meanings, generated by feelings. Hence the concept creation occurring in the text is an arena of pleasure, an erotic experience. R. Barthes asserts that not only the creation of the text, but also reading is associated with the pleasure, because to read means to desire the text, to strive to reincarnate into it, and the text itself must prove to the reader that exactly this reader is the most desirable. Generating text, thereby, seems to become the most prominent transgressive formation experience.

It is worth noting that such a fetishization of language in postmodernism bypasses the important point of linking language with thinking through forms of thinking: the word is the name of a concept, and the sentence constitutes a verbal shell of assertion or reasoning. In fact, because the concept (the essence of the object or phenomenon) has a volume (the number of objects thought in the concept) and content (features), the word has sense (the meaning of the concept) and meaning (the scope of the concept). Whereas conceptual thinking is not the only possible way to solve problems and tasks: there is still a subject (action) thinking when solving a problem occurs in the process of the immediate interaction with objects; and also imaginative (visual) thinking, when the problem is based on and solved by means of images, sensation and perception. Therefore, one can hardly claim that a person's mastery of a language is the one and only factor forming his or her ability to think. Conceptual (abstract, abstractly-logical) thinking is formed on the basis of mastering a system of concepts, fixed in words-names in the process of

\footnotetext{
${ }^{22}$ Мовне питання : за і проти. Львів: Соціологічна група “Рейтинг”, 2012. 40 с.
} 
assimilation of culture, condensed in linguistic form. Therefore, the thinking of a particular person seems to be derived from language, although language is only a means of conceptual thinking, and not a formative basis of it. In general, subject and imaginative thinking do not need words at all, because they are accomplished by other means, such as objects and images.

\section{CONCLUSIONS}

Such a brief and far not exhaustive overview of the psychological context of the postmodernism philosophy concepts prompts some debatable conclusions. In psychology, in fact, some basic principles of postmodernism have been dominated "by default" already for a long time. These principles are: the relativity of truth, the denial of absolutization, uncertainty, the apotheosis of unreasonableness, the idea that event is always ahead of theory, the doubt as the main method of cognition, and so on. From the first steps of its independent existence, psychology as a science had no clearly established subject and approaches to its study. Pluralism of approaches and theoretical paradigms in psychology can be regarded as its normal, habitual natural state. Therefore, no comprehensive categorical system of the fundamental psychology has been created yet. When psychologists become fascinated by the need to create such a unified system and to formulate general laws of the functioning of the psychic, it is in fact reminiscent of comparing science with detective and science fiction (J. Deleuze).

In general, the attempt to grasp the influence of postmodern philosophy on contemporary psychology suggests that the "inequality" of the relations between these sciences, which led to the creation of the Philosophy of Psychology, must be overcome by the creation of the Psychology of Philosophy. The subjects of the psychology of philosophy should be psychological mechanisms of the emergence and development of various philosophical views and currents, psychological characteristics of the authors of philosophical concepts and socio-psychological context of their lives, psychological analysis of cultural and historical epoch, the basis on which certain philosophical ideas were formed. This would allow us to understand more deeply the essence of philosophical concepts and views, to try to see the world through the eyes of their creators and to finally understand why, all trying to find the absolute truth in common, every researcher does it in different way; and also - why, proclaiming tolerance as their principle, everyone absolutizes his or her point of view. In the end, the anti-psychologism, fundamentally declared by postmodern philosophers as a fundamental rejection of the subjective factor in interpretation of cultural phenomena, led to creation of schizoanalysis, communication philosophy, and philosophical analysis of psychological phenomena such as identity, personality, language, feeling, etc. Practically, every postmodern philosopher analyzes the phenomena and processes 
that lie in the field of psychology, tries to use psychological approaches and methodologies to study these phenomena, to combine them with the philosophical context. The fates of philosophy and psychology, from ancient times and still nowadays, not simply intersect, but follow the same paths. No matter how hard one tried to separate the object and subject of these sciences, it is just as futile as are efforts to break the system of "person \& the world he/she lives in", so it seems impossible to radically disconnect philosophy and psychology. Descriptions of the ideas of the vast majority of eminent philosophers can be found not only in textbooks and monographs on the history of philosophy, but also in books entitled "History of Psychology" In which of these textbooks will we include sections on the ideas of Aristotle, G. Leibniz, W. James, Z. Freud, E. Fromm, A. Maslow, E. Erickson, L. Zoja, M. Foucault?

\section{SUMMARY}

The modern, or, we may say, postmodern world differs from the world where our ancestors lived. This is a world of rapid changes, globalization and personal freedom, the world in which a person has great opportunities for choice, but also faces the huge stress of responsibility for this choice. The postmodern philosophy and psychology try to study the nowadays reality and the person living within it and changing with it. Despite the declared separation of philosophy and psychology, these sciences are in fact deeply connected and actively interpenetrate. In particular, they use a list of common principles and concepts. This work is aimed to briefly overview some of the core concepts of the postmodern psychology, in their complex and interaction. Particularly, are provided descriptions and explanations of such concepts as rhizome, transgression, nomadology, synergy, discourse, identity, language. Also, is described the connection between postmodern psychology and philosophy, and their roles and functions in the postmodern world.

\section{REFERENSES}

1. Абушенко В.Л. Идентичность // Новейший философский словарь : 3-е изд., исправл. Минск: Книжный Дом, 2003. С. 400-404.

2. Браймен А., Белл Э. Методы социальных исследований. Группы, организации и бизнес / Пер. с англ. Харьков : Изд-во Гуманитарный Центр, 2012. 776с.

3. Гарифуллин Р.Р. Постмодернизм в психологии : монография // psyfactor.org/lib/postmodern-00.htm. 2010

4. Гваттари Ф., Делез Ж. Тисяча Плато. Капитализм и шизофрения. / Пер. с франц и послесл. Я.И. Свирского, научн. ред. В.Ю. Кузнецов. Екатеринбург : У-Фактория ; Москва : Астрель. 2010. 895 с.

5. Грицанов А.А., Мезяная К.Н. Пригожин // Новейший философский словарь : 3-е изд., исправл. Минск. : Книжный Дом, 2003. С. 798-799. 
6. Делез Ж. Логика смысла. Москва : Академический проект, 2011. $472 \mathrm{c}$.

7. Делез Ж., Гваттари Ф. Трактат о номадологии // Новый круг, 2005, № 2 (92). С. 183-187.

8. Дзоя Л. Історія гордині : психологія і межі розвитку / перекл. 3 італ. С. Сарвіра ; за фах. ред. Д. Залеського. Львів : Видавництво “Астролябія". 2019. 384 с.

9. Лиотар Ж.-Ф. Anima minima // Кабинет “3” / под ред В. Мазина. 2004. C. 62-97.

10. Мерфі Т. Ризома // Енциклопедія постмодернізму / за ред. Ч. Вінквіста, В. Тейлора. Київ, 2003. С. 361-362.

11. Мовне питання : за і проти. Львів: Соціологічна група "Рейтинг”, 2012. $40 \mathrm{c}$.

12. Можейко М.А., о. Сергий Лепин Дискурс // Новейший философский словарь : 3-е изд., исправл. Минск : Книжный Дом, 2003. С. 327.

13. Пригожин И., Стенгерс И. Порядок из хаоса. Новый диалог человека с природой. Москва : Прогресс, 1986. 432 с.

14. Татенко В. Суб'єктно-вчинкова парадигма в сучасній психології // Соціальна психологія, 2006, № 1. С. 3-13.

15. Тофлер Е. Третя хвиля. Київ : Вид. дім “Всесвіт”, 2000. 480 с.

16. Тофлер Э, Тофлер Х. Революционное багатство. Москва : АСТ, $2005.416 \mathrm{c}$.

17. Фаулз Дж. Пять повестей: Башня из черного дерева. Элидюк. Бедный Коко. Энигма. Туча / Пер. с англ. Москва : АСТ: АСТ МОСКВА, 2008. $444 \mathrm{c}$.

18. Фуко М. Порядок дискурса // Фуко М. Воля к истине: по ту сторону знания, власти и сексуальности. Работы разных лет / Пер. с фран. Москва : Касталь, 1996. С. 47-95.

19. Фуко М. Что такое Просвещение? // Фуко М. Интеллектуалы и власть. Москва : Праксис, 2002. Ч. І. С. 335-360.

20. Эриксон Э. Детство и общество. Санкт-Петербург : ЛЕНАТО ; АСТ; Фонд "Университ. кн”, 1996. 592 с.

21. Heckhausen H. (2010) Motivation and Action (PDF) (Paperback $2^{\text {nd }}$ ed) Cambridge University Press. P. 272-295.

Information about the author: Hrabovska S. L.,

$\mathrm{PhD}$, Professor, Head of the Department of Psychology Ivan Franko National University of Lviv 1, University str., Lviv, 79000, Ukraine 